\title{
The Bailey Point Region and Other Muskox Refugia in the Canadian Arctic: A Short Review
}

\section{C. THOMAS', F. L. MILLER', R. H. RUSSELL' and G. R. PARKER ${ }^{2}$}

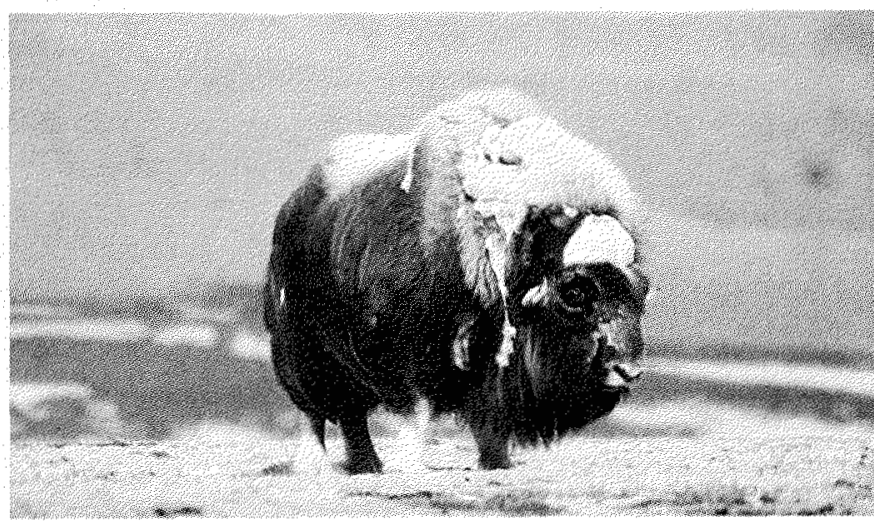

FIG. 1. Lone bulls, temporarily excluded from the herds by dominant bulls, are a common sight during the breeding season in August and September. (G. Parker)

The muskox (Ovibos moschatus) (Fig. 1) is widely distributed over much of arctic Canada but only at a few locations do their densities remain high and populations relatively stable. These refugia constitute the most favourable muskox ranges in the Canadian Arctic Archipelagoplaces where muskoxen probably would survive under the most unfavourable climatic conditions. Extremes in winter weather cause other populations to ride a roller coaster of ups and downs with local exterminations. Refugia for muskoxen in the High Arctic include lowlands on eastern Axel Heiberg Island in the Mokka Fiord region, the lowlands of northeastern Devon Island, and the Bailey Point region of Melville Island (Fig. 2). All of those regions historically have supported high densities of muskoxen from time to time but the Bailey Point region must be considered the best habitat for muskoxen in the Canadian High Arctic.

Bailey Point is located northwest of Dundas Peninsula, off the path of early explorers whose sea access to the region was restricted by ice, and land travel inhibited by deep bays and rugged terrain. Mecham (1855) in 1853 and Stefansson (1943) in 1916-17 travelled in winter along the south shore of western Melville Island. But the biological secrets of the Bailey Point region remained hidden until 1961 when the Canadian Wildlife Service conducted an aerial survey of the Queen Elizabeth Islands and noted many muskoxen on the relatively few meadows below the rugged hills of western Melville Island (Tener, 1963). It was not until the aerial surveys of 1972-74 (Miller et al., $1977)$ that the real significance of the Bailey Point region came to light. Subsequently no other group of muskoxen has been monitored so closely in Canada - a total of 12 surveys from 1972 to 1980 , at least one every year.
The Bailey Point region is a $640 \mathrm{~km}^{2}$ peninsula that extends into M'Clure Strait, separating Hardy Bay to the west from Murray Inlet to the east. Southwestern Melville Island consists of ridges and plateaus developed on terrain that has undergone Tertiary faulting (Tozer and Thorsteinsson, 1964). The Bailey Point region consists of a plateau rising to $750 \mathrm{~m}$, incised by stream valleys and bordered by a narrow strip of coastal lowlands. The lowlying coastal zone is more extensive than elsewhere on southwestern Melville Island but $52 \%$ of the land area is over $200 \mathrm{~m}$ in elevation.

The two dominant vegetation types on the plateau were named polar desert and moss-clay plateau by Parker and Ross (1976). The former is sparsely vegetated with grasses, forbs, and lichens; the latter supports mosses, grasses, and forbs. Wet meadows, supporting abundant sedges, are common at the base of the plateau. The coastal lowlands consist of two dominant vegetation types, termed clay barrens and clay-moss slopes. The clay barrens are common on elevated ridges and support a mosaic of willow (Salix arctica), Dryas integrifolia, and bare ground. The clay-moss slopes support vegetation of similar composition with greater percentage plant cover (Parker and Ross, 1976). The sedges and grasses of wet

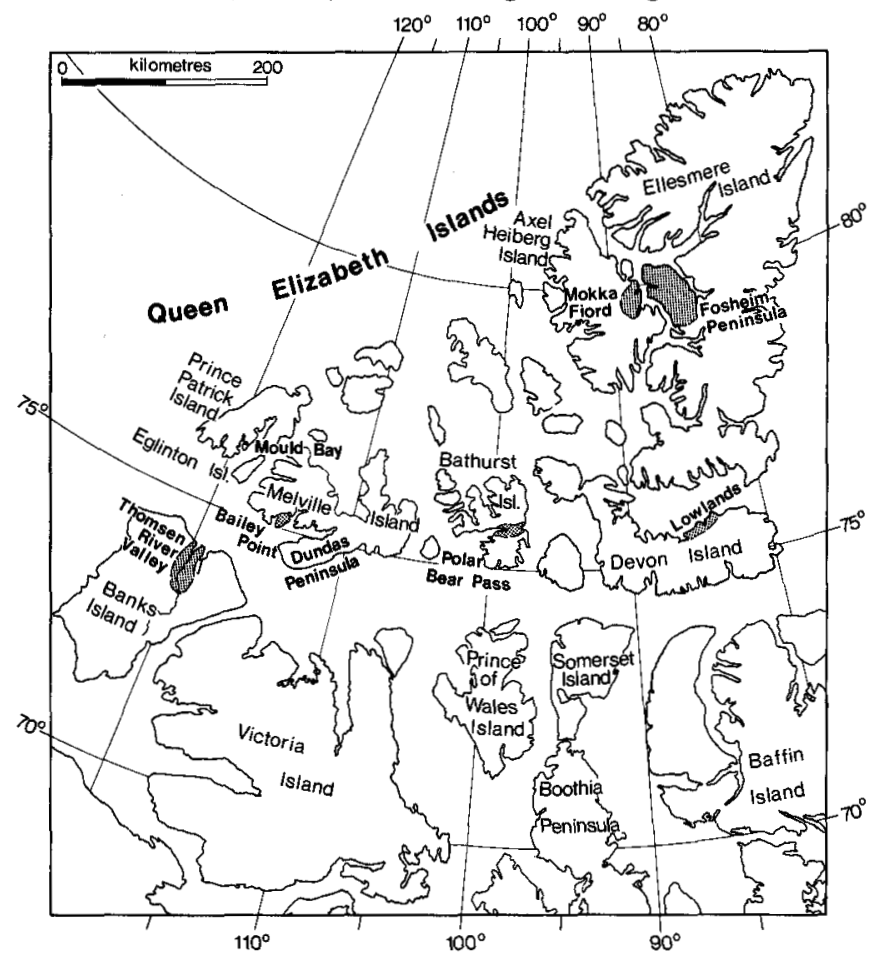

FIG. 2. Locations (stippled) in the Canadian Arctic Islands where the highest densities of muskoxen were recorded.

'Canadian Wildlife Service, 9942 - 108 Street, Edmonton, Alberta, Canada T5K 2J5

'Canadian Wildlife Service, P.O. Box 1590, Sackville, New Brunswick, Canada E0A 3C0 
meadows are the preferred diet of muskoxen in summer; in winter that food source is supplemented with a greater intake of willows, grasses, and sedges from the exposed slopes and ridges (Parker, 1978).

The numbers of muskoxen recorded on 12 aerial surveys of the Bailey Point region between 1972 and 1980 averaged 432 and varied from 234 in summer 1978 to 698 in winter 1976 (Table 1). The average counts in the eight winter and three summer surveys were 461 (368-673) and 275 (234-318), respectively. The 1976 winter counts of 698 and 647 were averaged to 673 before calculating the average for the eight winters. Calves of the year were excluded from survey totals of both seasons. Densities varied, ranging from 0.6-1.1 muskoxen $/ \mathrm{km}^{2}$ over the entire peninsula, from $1.0-2.0 / \mathrm{km}^{2}$ in ranges below $200 \mathrm{~m}$, and reaching $2.6 / \mathrm{km}^{2}$ below $100 \mathrm{~m}$. The highest recorded densities of muskoxen from other productive regions were $1.8 / \mathrm{km}^{2}$ in the Thomsen River Valley, Banks Island (Wilkinson and Shank, 1973), and $1.5 / \mathrm{km}^{2}$ on northeast Devon Island (Hubert, 1974). Before severe winter conditions reduced muskox numbers in Polar Bear Pass, Bathurst Island, densities reached $0.7 / \mathrm{km}^{2}$ (Gray, 1973). The outer Fosheim Peninsula - eastern Axel Heiberg range supported approximately 0.2 muskoxen $/ \mathrm{km}^{2}$ in 1961 (Tener, 1961), although a brief survey over eastern Axel Heiberg Island in 1973 showed that densities had increased to $0.7 / \mathrm{km}^{2}$.

TABLE 1. Numbers of muskoxen, excluding calves less than 6 months old, observed on 12 aerial surveys of the Bailey Point region (peninsula only) 1972-80.

\begin{tabular}{lccc} 
Year & Date & $\begin{array}{c}\text { Muskoxen' } \\
\text { observed }\end{array}$ & Observer \\
\hline 1972 & 6 April & 457 & Miller \& R. Russell \\
1973 & 7 April & 495 & Miller \& R. Russell \\
& 2 August & 274 & Miller \& R. Russell \\
1974 & 14 April & 450 & Miller \& R. Russell \\
& 30 July & 318 & Miller \& R. Russell \\
1975 & 28 March & 447 & Thomas \\
1976 & 16 February & 698 & J. Russell \\
& 28 March & 647 & J. Russell \\
1977 & 23 March & 410 & Thomas \\
1978 & 14 August & 234 & Thomas \\
1979 & 13 April & 384 & Gunn \\
1980 & 21 April & 368 & Thomas
\end{tabular}

'Excluding calves less than 6 months old.

The best muskox habitat below $200 \mathrm{~m}$ in Canada seemingly can support $1-2$ muskoxen $/ \mathrm{km}^{2}$ on a year-round basis if winters are not too severe. Most ranges in the Canadian Arctic Archipelago are subject to occasional icing and deep compacted snow, which can markedly reduce populations. This factor complicates any estimates of long-term carrying capacities of muskox range.

In the scanty literature concerning muskox populations on arctic islands there are several examples of herds disappearing or being markedly reduced by causes other than hunting: (1) Muskoxen disappeared from Prince Patrick
Island sometime between 1952 (MacDonald, 1954) and 1961 (Tener, 1961), only to recolonize the island by 1972 (Miller et al., 1977); (2) A severe winter in 1953-54 seemingly caused massive die-offs in Greenland and Canada; (3) Muskoxen were rare or absent from Banks Island early in this century (Stefansson, 1943) but by 1970 they were thriving on the northern portions of the island; (4) Muskoxen on Bathurst Island stopped reproducing for three years after an unfavourable winter in 1967-68 (Gray, 1973), and they were decimated by a $73 \%$ population decline in winter 1973-74 (Miller et al., 1977); (5) Muskoxen were common on the Dundas Peninsula, Melville Island, in 1916-17 when Stefansson (1943) relied on them for survival; none were seen there in 1961 (Tener, 1961) and they had recolonized it by 1972 (Miller et al., 1977); (6) On Greenland the species is subject to periodic die-offs and extinctions in large regions (Ferns, 1977).

Why is the Bailey Point region so important? We believe it is a critical refugium for muskoxen during periods when extreme climatic conditions decimate the herds on less favourable habitats on the western Queen Elizabeth Islands. As such, it serves as an important source of animals for restocking less-hospitable regions. The Bailey Point region has served both functions in recent years. Herds there were unaffected by the devastating winter of 197374 , which reduced herds on adjacent eastern Melville Island by $48 \%$ and on Bathurst Island by $73 \%$ (Miller et al., 1977). Emigration from Bailey Point of 200-300 muskoxen occurred during 1977-78. On 14 August 1978, during an aerial search, only 234 muskoxen $\left(0.4 / \mathrm{km}^{2}\right)$ could be found on the peninsula and another 36 nearby. Our observations of numerous calves and yearlings and only one relatively fresh carcass pointed to emigration as the cause of the reduction in numbers, rather than mortality caused by malnutrition. Many of the muskoxen may have moved to Dundas Peninsula where we recorded 213 animals on just two passes over it. Some unknown stimulus causes groups of muskoxen to strike out for new lands, an important adaptation in the Arctic Archipelago where subpopulations can be extinguished from islands or parts of islands.

What propitious circumstances of geography and climate produce a muskox haven at Bailey Point (Fig. 3)? First, the western High Arctic is in a zone of low total precipitation $(8.5 \mathrm{~cm} / \mathrm{yr})$ with average annual snowfalls of only $58 \mathrm{~cm}$ at the nearest weather station at Mould Bay on Prince Patrick Island. Second, the surrounding seas, particularly to the north, are mostly ice covered year-round and prevailing winter winds are out of the northwest quadrant; consequently rain or snow melt and subsequent ice formation is unlikely during winter. Third, the region generally is protected from prevailing northwest winds by interior highlands, and the lowlands are locally protected by the highlands of the peninsula, bordered on the windward side by impressive scarps. Fourth, the region contains productive lowlands and fertile stream valleys 


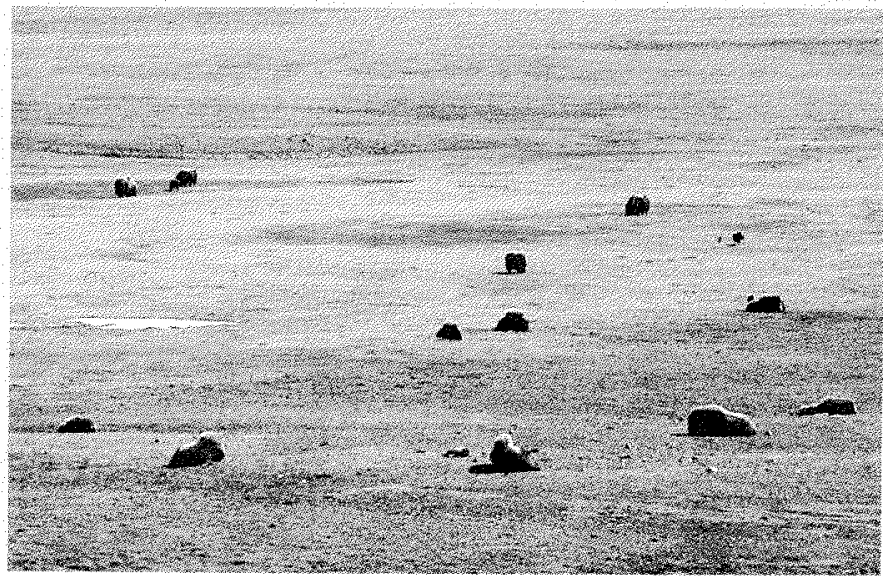

FIG. 3. Herds coalesce in winter: the average herd sizes, excluding calves less than six months of age, in summer and winter were 6.6 and 23.6, respectively. (G. Parker)

rounded by glacial action and overlain by till (Edlund, pers. comm.).

Other centres of muskox populations in arctic Canada have similar favourable characteristics that lessen or remove the potential for a winter disaster caused by deep, hard, and prolonged snow cover or groundfast ice, ice layering in the snow or icy crusting of the snow. For example, an early winter rain storm followed by heavy winter snows and a late summer can create such difficult foraging conditions that the majority of muskoxen in a population can starve in one winter. Worse still, two severe winters may occur consecutively or within a span of three years, leaving insufficient time for the animals to recover their fat reserves. Fortunately these conditions may only occur in a given region once every 10-50 years. Many populations seem to be in a state of recovery following sudden declines.

The muskoxen share their refugium at Bailey Point with several bird and other mammal species. The small, lightcolored Peary caribou (Rangifer tarandus pearyi) migrates through Bailey Point on its journey from wintering grounds on Eglington and Prince Patrick islands to summer pastures on the Dundas Peninusla and other regions of eastern Melville Island. In 1973, at Bailey Point, a wolf (Canis lupus) took a sandwich from one of us and other wolves showed neither fear nor aggression when their den was approached. The polar bear (Ursus maritimus) also uses the peninsula during seasonal movements through M'Clure Strait. Other land mammals frequently seen are the arctic fox (Alopex lagopus) and the collared lemming (Dicrostonyx groenlandicus), and less often the weasel (Mustela erminea) and arctic hare (Lepus arcticus).

The Bailey Point region is host to approximately 28 species of birds and forms the documented northern distributional limits of the sandhill crane (Grus canadensis), black-bellied plover (Squatarola squatarola), buff-breasted sandpiper (Tryngites subruficollis), willow ptarmigan (Lagopus lagopus), and pomarine jaeger (Stercorarius pomarinus) (Maltby, 1978).
Clearly the Bailey Point region should be afforded some protection from future developments. Seismic exploration scheduled for Bailey Point in late winter 1975 and 1976 fortunately was postponed. The region is proposed as an Ecological Site by the International Biological Program (IBP), and it has been examined by Parks Canada but was not given high priority as a future National Park. The Thomsen River Valley is protected to some extent by a Migratory Bird Sanctuary and it is included in proposed Ecological Sites and a proposed National Park. Polar Bear Pass on Bathurst Island was nominated as an IBP Site in 1975 and was given interim protected status under the Territorial Land Use Act in February 1978.

Perhaps the Bailey Point region should be considered as a National Wildlife Area with interim protection under the Territorial Lands Act. Biological gems are rare in the High Arctic - we must protect this one for future generations of man and muskoxen.

\section{ACKNOWLEDGEMENTS}

We thank John Russell and Anne Gunn, N.W.T. Wildlife Service, for their counts of muskoxen in 1976 and 1979, respectively. We also thank the Polar Continental Shelf Project and the Canadian Wildlife Service for their long-term support of this project.

\section{REFERENCES}

FERNS, P. N. 1977. Muskox abundance in the southern part of the range in east Greenland. Arctic 30:52-60.

GRAY, D. R. 1973. Social organization and behavior of muskoxen (Ovibos moschatus) on Bathurst Island, N.W.T. Ph.D Thesis, University of Alberta, Edmonton. 212 p.

HUBERT, B. 1974. Estimated productivity of muskox (Ovibos moschatus) on northeastern Devon Island, N.W.T. M.Sc. Thesis, University of Manitoba, Winnipeg. $118 \mathrm{p}$.

MACDONALD, S. D. 1954. Report on biological investigations at Mould Bay, Prince Patrick Island, N.W.T. Annual Report of the National Museums of Canada, 1952-53. Bulletin No. 132:214-238.

MALTBY, LYNDA S. 1978. Birds of the coastal zone of Melville Island, 1973-1975. Canadian Field Naturalist 92(1):24-29.

MECHAM, G. F. 1855. Travelling journal of Lieutenant Mecham. British Parlimentary Papers:499-540.

MILLER, F. L., RUSSELL, R. H. and GUNN, A. 1977. Peary caribou and muskoxen on western Queen Elizabeth Islands, N.W.T. 1972-74. Canadian Wildlife Service Report Series No. 40. 55 p.

PARKER, G. R. 1978. The diets of muskoxen and Peary caribou on some islands in the Canadian High Arctic. Canadian Wildlife Service Occasional Paper No. 35. 21 p.

and ROSS, R. K. 1976. Summer habitat use by muskoxen (Ovibos moschatus) and Peary caribou (Rangifer tarandus pearyi) in the Canadian High Arctic. Polarforschung 46(1):12-25.

STEFANSSON, V. 1943. The Friendly Arctic. New York: MacMillan Co. $812 \mathrm{p}$.

TENER, J. S. 1961. Queen Elizabeth Islands game survey. Canadian Wildlife Service Report CWSC 972.94 p.

1963. Queen Elizabeth Islands game survey. Canadian Wildlife Service Occasional Paper 4. 50 p.

TOZER, E. T. and THORSTEINSSON, R. 1964. Western Queen Elizabeth Islands, Arctic Archipelago. Ottawa: Geological Survey of Canada. Memoir 332. 242 p.

WILKINSON, P. F. and SHANK, C. C. 1973. The range relationship of muskoxen and caribou in northern Banks Island in summer 1973: A study of interspecies competition. Report to N.W.T. Game Management Division. 744 p. 